\title{
Analysis of Implementation of E-Legislation Based on Public Participation at the National Law Development Agency
}

\author{
Ari Khusrini' ${ }^{1}$, Teguh Kurniawan ${ }^{2}$ \\ Study of E-Government, Faculty of Administrative Sciences, University of Indonesia \\ Email: heavensoase@gmail.com ${ }^{1}$, teguh.kurniawan@ui.ac.id ${ }^{2}$
}

(Received: May 15-2019; revised: Juny 10-2019; published: December 31-2019)

\begin{abstract}
Previous studies of e-rulemaking that have not touched the theme of e-rulemaking in Indonesia or elegislation, findings of the observations of the BPHN's website are technical constraints and low public comment statistics, the urgency of the needs of the Indonesian Government in improving democracy and the quality of policies, as well as the legal vacuum regarding the provision of the implementation of elegislation since 2014 until now, hence the review of this paper will be focused on the preparation of a research framework to address the quality of implementation of public participation with e-legislation. The qualitative research method used is literature review and observation on the BPHN's website with a study period of October 2016-January 2019. The results of the literature review show, conceptually, quality of the e-rulemaking cannot only be seen from a large number of participants, but rather to the quality of comments that has a substantial depth to get the quality of policy and compliance in its implementation. The dimension of public administration is used to photograph the stages: (i) system input; (ii) system process, including processing and managing data and information; and (iii) the quality of public comments and the policy of draft output.
\end{abstract}

Keywords: e-rulemaking, BPHN, public participation, e-legislation

\section{INTRODUCTION}

The dynamic of technology development has influenced all aspects of human life. Internet Communication Technology (ICT) becomes important in the formation of policies and regulations (rulemaking) in terms of accelerating the dissemination of information to the public in order to revive good governance. Rulemaking, according to Law \& Lau (2006) is a comprehensive view of lawmaking activities includes drafting laws/regulations, notifications, and public comments, regulatory validation, a publication of regulations, and compliance and law enforcement. While electronic rulemaking (e-rulemaking) is the use of ICT in the process of rulemaking.

Shulman, Schlosberg, Zavestoski, \& Courard-Hauri (2003) in the Electronic Rulemaking a Public Participation Research Agenda for the Social Sciences stated that, Governments in the world do not escape from various problems including environmental problems, the solution to the problem depends on the science underlying the problem, the use of internet technology can provide a flexible mechanism and can make easy for public participation, and the potential to preserve infrastructure that can facilitate unique process and culturally specific. In order to answer various problems, the Governments in the world began to transform along with the development of information technology in the process of contemporary lawmaking by using a 
126 | Jurnal Ilmiah Ilmu Administrasi Publik: Jurnal Pemikiran dan Penelitian Administrasi Publik Volume 9 Number 2,July - December 2019. Page 125-136

web-based program to collect public comments about the draft regulation as a voice channel of democration (Shulman et al., 2003), technology helps identify new process in the policy formation process (Williams, 2009), namely by the mechanism of e-rulemaking which includes drafting laws/regulations, notification and public comments, regulatory validation, publication of regulations, and compliance and law enforcement (Law and Lau 2006).

Digital technology is a public media inclusiveness that enables the term of electronic mechanism in: sharing information, giving input from the public, and making decisions become real. In sequential term, the term describes the level of maturity of the e-government that is more open in sharing information, consideration, and even authority in a public participatory context in the policy cycle. A number of countries have simultaneously carried out the electronification mechanism of public participation in drafting Government regulations in various government sectors (including the sectors of: health, taxation, population administration, and licensing) by actively involving the public to use media of Information Communication Technology (ICT). Trends in the use of ICT in the formulation of Government regulations involving broad public participation or e-rulemaking have been running in countries in the world, both developed and developing countries, including: Britain, South Korea, South Africa, Mexico, Jordan, Iraq, Belarus, Croatia, Germany, Vietnam, and Spain.

The results of the study of the practice of e-rulemaking in the world have broadly mapped the urgency or benefits, preconditions, barriers encountered. The benefits of e-rulemaking include:

1. increasing of substantial in potential that changes the process and use of information on regulations; improvement to internal government operation, increasing transparency and public involvement, creating more productive consideration and collaboration mechanism, reducing delay, simplifying terminology, more consistent in drafting document format, easy to understand, and improving regulatory outcomes; and increasing the potential to coordinate law, regulation, legal review, compliance, law enforcement, and program evaluation (Khusrini \& Juwono, 2018);

2. promising the creation of new opportunities for public deliberation in making regulations; increasing the legitimacy of democracy, increasing public understanding of rulemaking, making the process more interactive and deliberative, and making it easier for institutions that are more democratically responsible, such as the legislative, to oversee the regulatory process; ensuring better decisions, it is easier for regulator to analyze large volumes of data taken from various sources, helping analysts to make better predictions; reducing administrative burden, allowing agency manager to efficiently coordinate regulatory staff and other resources; expansion of compliance with regulations, increasing public understanding of what regulations are needed and reducing compliance costs through ICT (Anttiroiko, 2006);

3. drafting the law became more citizen-centric and promoting business innovation; as a multidisciplinary research platform (Law and Lau 2006); and 
4. improving traditional democratic processes, providing more technical and political opportunities for citizens in the political process, and leading to increased government transparency (Harechko, 2011).

The general use of e-rulemaking which can be concluded from the results of research is: (i) the more effective and efficient of the Government internal administration; (ii) improving the quality of Government policies; and (iii) increasing understanding, ownership and public compliance with rules.

The foregoing implies a bright side from the implementation of e-rulemaking. However, the perception of the usefulness of e-rulemaking is criticized skeptically by Zavestoski, Shulman, \& Schlosberg (2006), based on the results of research in the United States, erulemaking provides an arena for playing three types of conflicts that have long interfered with the decision-making process, namely: (i) the issue of trust in federal institutions; (ii) the use of science; and (iii) the role of public values. In addition to the benefits, in practice, e-rulemaking does not escape the barriers that must be considered and addressed in order to optimize the objectives of e-rulemaking itself.

Barriers in the implementation of e-rulemaking were identified by researchers, among others, namely:

1. silos for operating steps that result in delay, confusion, and loophole to make mistakes (Khusrini \& Juwono, 2018);

2. the moderation policy of comments is not carried out in objective standards that cause time delay (Dooling, 2011);

3. big data processing problem for government agencies (Law \& Lau, 2006);

4. dominance of certain interest groups without being able to be controlled by the agency (Jones, 2010);

5. weaknesses of the data security system (Lubbers, 2010);

6. internet connection instability; lack of responsiveness and feedback from the Government to the community (Welch, Hinnant, \& Moon, 2004);

7. the absence of a state transformation framework (Boyer, 1990); and

8. motivational, cognitive, and substantial information that is insufficient (Coglianese, 2004).

Thus, the barriers to implementing e-rulemaking, in general, are: (i) the absence of a comprehensive, integrated and standardized e-rulemaking framework (legally and technically); (ii) inability to provide resources that are suitable for system requirements (sources of funds and human resources); (iii) the weak of work ethic of the system organizer in terms of responsiveness and control; (iv) lack of substance in the information provided; (v) low public motivation.

Precondition as an ideal condition is urgently needed to ensure e-rulemaking runs effectively and efficiently by answering the potential risks of barriers that may arise as mentioned above. This was done before the official implementation of e-rulemaking was launched or generally called precondition. The application of e-rulemaking has preconditions that must be met, namely e-readiness. (Seliger, 2010) defines that, e-readiness is a form of readiness of a country, region or entity (for example, a corporation) to utilize information and 
128 Jurnal Ilmiah Ilmu Administrasi Publik: Jurnal Pemikiran dan Penelitian Administrasi Publik Volume 9 Number 2,July - December 2019. Page 125-136

communication technology to maintain prosperity and growth. Whereas according to Jukic, Kunstelj, Decman, \& Vintar (2009), e-readiness is the maturity of citizens, businesses, nongovernmental organizations/NGOs and the Government to participate in the world of electronics (e-commerce, e-government, etc.). Thus, e-readiness is considered important to be studied before the implementation of the electronic mechanism is carried out. Pre-condition findings as ideal system requirements, then faced with the existing conditions that will produce a map containing suitability and/or gap which must then be answered with a strategy to ensure that the objectives of e-rulemaking are achieved.

Public participation is a core concept of the practice of e-rulemaking in order to realize the quality improvement of the policies produced. The definition of public participation is the process of public concern, needs, and values that are incorporated into government decision making, in the form of two-way communication and interaction, with the aim of producing better decisions that are supported by the public (Creighton, 2005). Thus, the principle of public policy, namely prioritizing the interests of policy stakeholders in each policy taken with involvement or community participation becomes important as one of the sources of public intervention in order to open wider democratic channels in order to improve the quality of better public policies Badranaya (2006), Rokilah (2018), and (Rosalina, 2014), and increasing public acceptance in the policy implementation phase (Simpson \& Clifton, 2014). The role of the Government, in this case, is to identify potential negative externalities and strengthening the directing function (Lewis \& Marsh, 2012). Furthermore, in the dimension of public policy, it is closely related to codified basic norms that describe authority, provisions and become a reference for taking actions in the context of policy. This was agreed by (Coglianese, 2004) that, joint consensus (Government and public) on compiled regulations becomes important with hope to get high acceptability either socially, economically and politically so that the law can be enforced more effectively and efficiently. As for the role of the advancement of information technology will greatly expand the potential of public participation in making such policies. As such, public participation in e-legislation is urgently needed and e-legislation becomes a meeting point between the government and public interests.

\section{METHOD}

This article is a review paper that uses qualitative research method in the form of literature review of various relevant literature, including $\div$ provisions for regulation and policy planning for the e-legislation program, and theoretical and practical reviews of e-rulemaking and public participation; and observation activities on public participation portals on the website of BPHN. The literature study data is obtained from official academic journals, from the results of previous studies in the form of articles and books; credible sources from international institutions in the form of research reports; and the results of expert writings presented in discussion activities with limited circulation. While statistical and technical data is obtained by conducting direct research on the results of observations on the Ministry of Law and Human Rights' BPHN portal with data series starting in October 2016 until January 2019. The data in 
question is collected, processed, and analyzed in order to answer the research problems appropriately.

\section{RESULT AND DISCUSSION}

Along with the development of world ICT in terms of e-rulemaking that there is the potential for an increase in the number of public participation before and after the mechanism of e-rulemaking, especially those originating from interest groups (Stromer-Galley, Webb, \& Muhlberger, 2012), however, Benjamin (2005) argues, a more comprehensive study is needed with the support of sufficient data to prove empirically the notion that e-rulemaking will capture benefits that are better compared to the resources invested.

Furthermore, (Farina, Newhart, \& Heidt, 2012) criticize e-rulemaking in the context of public participation, testing causality relationship that is generally believed but it is considered not confirmed in practice, namely, the more the amount of public participation, the better Government policy making will be. The above assumptions are based on a series of causality, including: (i) if the public is given the opportunity to participate, they will use it; (ii) if the public is given information that the Government is making an important decision for the public, then the public will care about the decision making; (iii) if the public is given relevant information, it will be used meaningfully; (iv) if the Government embodies this, the public will enthusiastically welcome; and (v) if the public has participated, there will be better Government policies.

This is answered in the study, namely, the causal relationship in question depends on the design of e-rulemaking being built. Departing from the initial conclusions, the draft of the erulemaking design recommendations are drawn up which can be a reference to the positive realization of causality above, namely by designing responsible e-rulemaking. The design of the e-rulemaking can begin with: (i) defining the type of public participation needed (who, what, when); (ii) tailored made for the type of information given to each stakeholder with their interests to build attention and motivation; (iii) attention to the capacity and capabilities of Government agents is needed in terms of assessing, identifying and analyzing, and taking priority decisions in the formation of regulations; and (iv) efforts from the community side in the form of investing time and resources in accessing and participating in e-rulemaking.

The Government of Indonesia since 2004 through Law Number 10 of 2004 concerning Establishment of Law and Regulations amended by Law Number 12 the Year 2011 and Presidential Regulation Number 87 the Year 2014 as the implementing regulation, has opened conventional public consultation channel as well as using ICT media that enable the public to participate in e-rulemaking. Public involvement in e-rulemaking in Indonesia or called as elegislation. In this case, the e-legislation program as stated in the National Law Development Document in Indonesia in the national scope is the duty and authority of the Ministry of Law and Human Rights (Kemenkumham) with the implementing unit, namely, the National Legal Development Agency (BPHN). Until now, the technical provisions for implementing elegislation are still in the form of a Draft Regulation of the Minister of Law and Human Rights concerning the Implementation of Public Consultation in the Establishment of Law and 
130 | Jurnal Ilmiah Ilmu Administrasi Publik: Jurnal Pemikiran dan Penelitian Administrasi Publik Volume 9 Number 2,July - December 2019. Page 125-136

Regulations, which has caused the condition of a legal vacuum, the regulation draft as referred to is as attached. In this case, it means that e-legislation cannot be said as a policy yet.

However, research on e-legislation is worthy of further research by considering things, namely:

1. referring to the urgency of e-rulemaking or in this case e-legislation namely, (i) increasing public access to democracy; (ii) increasing the effectiveness and efficiency of the Government's internal administrative process; (iii) improving the quality of Government policies; and (iv) increasing of understanding, ownership and public compliance with rules, so that the rule of law can be enforced;

2. barriers to the implementation of e-rulemaking, in general, are: (i) the unavailability of strategic e-rulemaking framework (both legally and technically) that are comprehensive, integrated and standardized; (ii) inability to provide funding resources and human resources needed by the system (iii) the weak work ethic of the system organizer in terms of responsiveness and control; (iv) lack of substance of information; (v) low public motivation;

3. Referring to the same causality relationship with the results of Farina and colleague's research on conceptual work and practical observation in the United States Regulations.gov which is a developed country that, the more the amount of public participation, it will improve the quality of Government policy, but in reality requires certain terms and conditions, then skeptical thinking arises, will the practice be similar in developing countries like Indonesia, with differences including: governance, resources, level of education quality, and social culture?;

4. the needs of the Indonesian Government for quality and successful policy products in achieving development goals conducted through the e-legislation program and focusing on an effective and efficient process both from the Government side as the organizing of government affairs, and from the public side in general in terms of support in the policy cycle;

5. the results of preliminary observations on the BPHN website still indicated a technical problem: (i) still lack of introductory information about the program in the form of history and legal basis so that the public with diverse levels of education and knowledge do not get an introduction to the knowledge base regarding the concept and context of e-legislation and this is one of the barriers in starting its contribution to the system in question; (ii) the explanation of the substance distribution of material (especially the evaluation of Laws and Regulations and academic texts) presented is not clear, so that the instant information regarding the concept of input that is expected to be given by the public is not obtained; (iii) the substance of the type of input is not yet in accordance with the material requirements of different academic texts, so it can be ascertained that public input will not be in accordance with the needs of material substance; (iv) on the Prolegnas material even only presents a draft list of Laws and Regulations which will be discussed without the filling form for the public to provide input, so the concept of public consultation in the National Legislation Program is not reflected; (v) illustration of the business process of the e-legislation system not yet presented both in the form of narratives and infographics, thus providing barriers to 
the distribution of information for the public who want to give their participation in the system; (vi) there are documents that still cannot be downloaded and some document views still have errors (especially in academic text material), so that it becomes a barrier for the public to be able to access the academic texts intended for further study in order to provide productive input to build the formulation of academic texts; (vii) application that is built has not been properly able to be accessed using a smartphone due to the limited ownership of a computer or laptop, and wired internet access, meanwhile on the other hand smartphone ownership and use and cellular internet networks which are actually increasingly massive in Indonesia; this what prevents the public at large from being able to access e-legislation wherever and whenever via a smartphone; (viii) the application system is still one way (not interactive yet), there is no personal chat, interactive forums, or direct feedback to the public that provides input, so that engagement with the public is not formed, and raises the potential for gradual decline in public interest in providing input to the system; and (ix) presentation of input resume data is still limited to quantitative measures, in this case the quality of public input is not displayed in terms of the number of inputs that can be used in the formulation and evaluation of the Draft Laws and Regulations, academic papers, and Laws and Regulations that have been issued, so that information for internal (BPHN) for the justification of optimizing the use of the e-legislation system is difficult to be formulated empirically and this means that for the public it will erode the motivation for participation in e-legislation (bphn.go.id, accessed on 12 January 2019);

6. the level of public curiosity was high, but the number of low realization comments was reflected in the total hits that increased from 35,858 per October 1, 2016 to March 31, 2018 to 52,491 times as of January 12,2019 . However, the total comments coming in decreased from 1.14 percent to 0.82 percent, as shown in Table 1 below.

Table 1.

Statistical Data on Public Participation in Implementation E-legislation October 1, 2016 - January 12, 2019

\begin{tabular}{|l|l|c|c|}
\hline \multicolumn{1}{|c|}{ Period } & \multicolumn{1}{c|}{ Total Hit } & \multicolumn{2}{c|}{$\begin{array}{c}\text { Total comments } \\
(\%)\end{array}$} \\
\hline October 1, 2016 until March 31, 2018 & 35.858 & 409 & 1,14 \\
\hline October 1, 2016 until January 12, 2019 & 52.491 & 429 & 0,82 \\
\hline
\end{tabular}

Source: BPHN Website, 2016-2019

7. referring to the condition that, until now no research has been conducted on the practice of the intended e-legislation.

Referring to the things above, it becomes interesting if further research is done on aspects: information technology, agency management, public participation, and regulatory compliance, (Coglianese 2007). Thus, in assessing the implementation of e-legislation in terms of aspects of public participation, it is recommended to use the dimensions of public administration by portraying the stages of the management process, namely: (i) system input as precondition that 
132 |Jurnal Ilmiah Ilmu Administrasi Publik: Jurnal Pemikiran dan Penelitian Administrasi Publik Volume 9 Number 2,July - December 2019. Page 125-136

must be met before implementation is carried out; (ii) system processes, including processing and managing data and information; and (iii) the quality of public comments and output of policy draft that will be recommended during joint discussions between the executive and the legislative. Concretely, the variable to be examined is the quality of the implementation of elegislation. As for the operational dimension and definition as shown in Table 2 below.

Table 2.

Concept of Operationalization

\begin{tabular}{|c|c|}
\hline Dimension & Indicator \\
\hline $\begin{array}{l}\text { 1. Social environment (one of } \\
\text { the prerequisites for ICT users } \\
\text { in the implementation of e- } \\
\text { legislation is in the form of } \\
\text { supporting social } \\
\text { environmental condition } \\
\text { includes education level, } \\
\text { participant motivation, and } \\
\text { ICT literacy) }\end{array}$ & $\begin{array}{l}\text { 1. Level of education (measured by school life and } \\
\text { participation rates) } \\
\text { 2. Motivation (all forms of encouragements which is the } \\
\text { basis of a decision and public behavior in e- } \\
\text { legislation) } \\
\text { 3. ICT Literacy (level of mastery and use of ICT by the } \\
\text { public) }\end{array}$ \\
\hline $\begin{array}{l}\text { 2. E-rulemaking Framework (a } \\
\text { complete framework for the } \\
\text { implementation of e- } \\
\text { rulemaking includes: legal } \\
\text { basis framework, and } \\
\text { technical in the form of a } \\
\text { governance process } \\
\text { mechanism, ICT } \\
\begin{array}{l}\text { infrastructure planning, and } \\
\text { human resources) }\end{array}\end{array}$ & $\begin{array}{l}\text { 1. The existence of regulations is needed (the entire state } \\
\text { legal framework governing all aspects relating to e- } \\
\text { legislation) } \\
\text { 2. Effectiveness of the substance of regulation } \\
\text { (assessment of the use of existing regulatory } \\
\text { substances in supporting the implementation of e- } \\
\text { legislation) } \\
\text { 3. Type of participation (who, what, when) (classification } \\
\text { type of participation includes: who are the subjects of } \\
\text { e-legislation; what or the depth of substance of the } \\
\text { incoming comments; and when or the right time, } \\
\text { measurable, and predictable on the schedule of giving } \\
\text { input) } \\
\text { 4. Comment processing (the mechanism for processing } \\
\text { comment data input that will be chosen to be the } \\
\text { substance of the regulation consulted with the public) } \\
\text { 5. Planning for ICT needs (planning system requirements } \\
\text { in the form of hardware, network infrastructure, and } \\
\text { applications, as well as back up planning, disaster } \\
\text { recovery site, and other things) }\end{array}$ \\
\hline
\end{tabular}




\begin{tabular}{|c|c|}
\hline & $\begin{array}{l}\text { 6. Planning for human resource needs (planning for } \\
\text { brainware needs that support the system as a whole) } \\
\text { 7. Information dissemination strategy (strategic steps in } \\
\text { conveying information on the existence, importance, } \\
\text { and mechanism of e-legislation to the public through } \\
\text { various communication media) } \\
\text { 8. Model of implementing organizational structure } \\
\text { (organizational model of the implementing executive } \\
\text { unit in the implementation of e-legislation) }\end{array}$ \\
\hline $\begin{array}{l}\text { 3. Quality of Portal (is a degree } \\
\text { of assessment of the reliability } \\
\text { of features on the e-legislation } \\
\text { portal and the quality of } \\
\text { information about the } \\
\text { substance of the draft } \\
\text { regulation consulted with the } \\
\text { public) }\end{array}$ & $\begin{array}{l}\text { 1. Technical quality (degree of assessment of the } \\
\text { reliability of the features required by the e-legislation } \\
\text { system in the website or e-legislation portal) } \\
\text { 2. Quality of information (quality of substance } \\
\text { information presented on a regulation plan consulted } \\
\text { with the public) }\end{array}$ \\
\hline $\begin{array}{l}\text { 4. Resources (is an inventory of } \\
\text { existing resource support for } \\
\text { the implementation of e- } \\
\text { legislation covering: } \\
\text { availability and adequacy of } \\
\text { funding sources; and the } \\
\text { capacity and capability of the } \\
\text { human resources) }\end{array}$ & $\begin{array}{l}\text { 1. Availability of existing funding sources (conditions of } \\
\text { existing or not existing, and the pattern of allocation of } \\
\text { funding sources at the BPHN financial planning } \\
\text { document) } \\
\text { 2. Adequacy of the number of existing funds (assessment } \\
\text { of the adequacy of the number of sources of funds for } \\
\text { the needs of implementing e-legislation) } \\
\text { 3. The capability of existing human resources (specific } \\
\text { capabilities of existing human resources in } \\
\text { implementing e-legislation) } \\
\text { 4. The capacity of existing human resources (assessment } \\
\text { of the carrying capacity of human resources in terms of } \\
\text { number and workload in the implementation of e- } \\
\text { legislation) }\end{array}$ \\
\hline $\begin{array}{l}\text { 5. Communication } \\
\text { stakeholders }\end{array}$ & $\begin{array}{l}\text { 1. Informal communication (all forms of communication } \\
\text { between stakeholders carried out in the implementation } \\
\text { of e-legislation) } \\
\text { 2. Formal communication (all forms and guidelines for } \\
\text { formal communication between stakeholders carried } \\
\text { out in implementing e-legislation) }\end{array}$ \\
\hline 6. E-legislation output & $\begin{array}{l}\text { 1. Quality of public comments (assessment of the degree } \\
\text { of fulfillment of the substance needed in e-legislation } \\
\text { derived from the input of public comments) }\end{array}$ \\
\hline
\end{tabular}


134 | Jurnal Ilmiah Ilmu Administrasi Publik: Jurnal Pemikiran dan Penelitian Administrasi Publik Volume 9 Number 2,July - December 2019. Page 125-136

\begin{tabular}{|l|l|}
\hline 2. & $\begin{array}{l}\text { The quality of the regulation draft produced by e- } \\
\text { legislation (the assessment of the substantial degree of } \\
\text { adequacy of the regulation draft as the output of e- } \\
\text { legislation that will be used as input in the process of } \\
\text { further policy discussion) }\end{array}$ \\
\hline
\end{tabular}

Source: Processed by Researchers, 2019

It is expected to use the above dimensions as the basis of the research framework, then it will illustrate the quality of the implementation of e-legislation in terms of aspects of public participation, so that it can provide conclusion for analyzing existing condition to be used as the basis for preliminary evaluation and the formulation of recommendations towards the inauguration of e-legislation into a complete policy that has a certain quality, effective, and efficient in achieving its objectives. Furthermore, by paying attention to the opinion of Labelle, (2005) where assessment must be more centered among others on cultural sensitivity, ICT mastery; for this purpose, qualitative research method is used by taking public perception of the informant of the Government as e-legislation agency, academics, Non-Governmental Organizations as government watcher, public who has given their participation, as well as the public who have not provided their participation by using technical triangulation analysis.

\section{CONCLUSION}

The leadership style of the Aliyah Madrasah in the North District of Polongbangkeng District has leadership styles that have leadership aspects, directive, supportive, participatory and achievement oriented leadership. In addition, the motivation and work discipline of teachers at the Aliyah Madrasah in North Polongbangkeng Subdistrict, Takalar District are in a very high category. There is also an influence between the leadership style of the Madrasah Aliyah head towards work discipline and teacher motivation.

\section{REFERENCES}

Anttiroiko, A.-V. (2006). Encyclopedia of digital government. IGI Global.

Badranaya, D. (2006). Analisa kebijakan peningkatan partisipasi publik dalam proses perumusan kebijakan publik: Studi kasus di wilayah Kota Bandung. FE-UI.

Benjamin, S. M. (2005). Evaluating e-rulemaking: Public participation and political institutions. Duke LJ, 55, 893.

Boyer, W. W. (1990). Political science and the 21st century: from government to governance. PS: Political Science \& Politics, 23(1), 50-54.

Coglianese, C. (2004). Information technology and regulatory policy: New directions for digital government research. Social Science Computer Review, 22(1), 85-91.

Creighton, J. L. (2005). The public participation handbook: Making better decisions through citizen involvement. John Wiley \& Sons.

Dooling, B. C. E. (2011). Legal Issues in E-Rulemaking. Admin. L. Rev., 63, 893. 
Farina, C. R., Newhart, M., \& Heidt, J. (2012). Rulemaking vs. democracy: Judging and nudging public participation that counts. Mich. J. Envtl. \& Admin. L., 2, 123.

Harechko, I. (2011). Basic mechanisms of e-participation of citizens in policy-making. Toruńskie Studia Międzynarodowe, 1(4), 21-32.

Jones, G. D. (2010). Electronic rulemaking in the new age of openness: Proposing a voluntary two-tier registration system for regulations. Gov. Administrative Law Review, 1261-1285.

Jukic, T., Kunstelj, M., Decman, M., \& Vintar, M. (2009). E-Government in Slovene Municipalities: Analysing Supply, Demand and its Effects. In Handbook of research on strategies for local e-government adoption and implementation: Comparative studies (pp. 163-184). IGI Global.

Khusrini, A., \& Juwono, V. (2018). Public Participation in Electronic Rulemaking. ICASPGS, 72.

Labelle, R. (2005). ICT formulation and e-strategy development: a comprehensive guidebook. Bangkok: UNDP-APDIP.

Law, K. H., \& Lau, G. T. (2006). E-Rulemaking: Needs from ICT Perspectives. ERulemaking at the Crossroads, 11.

Lewis, C., \& Marsh, D. (2012). Network governance and public participation in policy-making: Federal community cabinets in Australia. Australian Journal of Public Administration, $71(1), 6-19$.

Lubbers, J. S. (2010). A survey of federal agency rulemakers' attitudes about e-rulemaking. Admin. L. Rev., 62, 451.

Rokilah, R. (2018). Implikasi Kewarganegaraan Ganda bagi Warga Negara Indonesia. Ajudikasi: Jurnal Ilmu Hukum, 1(2).

Rosalina, R. (2014). Pengaruh free cash flow terhadap nilai perusahaan melalui keputusan pendanaan dan kebijakan dividen pada perusahaan manufaktur yang listing di BEI tahun 2012. Pengaruh Free Cash Flow Terhadap Nilai Perusahaan Melalui Keputusan Pendanaan Dan Kebijakan Dividen Pada Perusahaan Manufaktur Yang Listing Di BEI Tahun 2012/Reni Rosalina.

Seliger, B. (2010). e-Government in a Federal State: The Case of the Introduction of eGovernment in Germany in the Early 2000s. In Handbook of Research on E-Government Readiness for Information and Service Exchange: Utilizing Progressive Information Communication Technologies (pp. 381-394). IGI Global.

Shulman, S. W., Schlosberg, D., Zavestoski, S., \& Courard-Hauri, D. (2003). Electronic rulemaking: A public participation research agenda for the social sciences. Social Science Computer Review, 21(2), 162-178.

Simpson, G., \& Clifton, J. (2014). Consultation, Participation and Policy-Making: Evaluating Australia's Renewable Energy Target. Australian Journal of Public Administration, 73(1), 29-33.

Stromer-Galley, J., Webb, N., \& Muhlberger, P. (2012). Deliberative e-rulemaking project: challenges to enacting real world deliberation. Journal of Information Technology \& Politics, 9(1), 82-96.

Welch, E. W., Hinnant, C. C., \& Moon, M. J. (2004). Linking citizen satisfaction with egovernment and trust in government. Journal of Public Administration Research and Theory, 15(3), 371-391. 
136 |Jurnal Ilmiah Ilmu Administrasi Publik: Jurnal Pemikiran dan Penelitian Administrasi Publik Volume 9 Number 2,July - December 2019. Page 125-136

Williams, M. F. (2009). Understanding public policy development as a technological process. Journal of Business and Technical Communication, 23(4), 448-462.

Zavestoski, S., Shulman, S., \& Schlosberg, D. (2006). Democracy and the environment on the internet: electronic citizen participation in regulatory rulemaking. Science, Technology, \& Human Values, 31(4), 383-408. 